\title{
Who Counts as a Muslim? Identity, Multiplicity and Politics
}

\section{SABA FATIMA}

\begin{abstract}
My aim in this paper is to carve out a political understanding of the Muslim identity. The Muslim identity is shaped within a religious mold. Inseparable from this religious understanding is a political one that is valuable in its own right in order to secure any sustainable possibility of participating politically as Muslims within a democratic liberal democracy, such as the United States. Here I explore not the historical or theological formation of the Muslim identity, rather a metaphysical understanding of it, in order to mobilize politically while avoiding the traps of essentialism. I begin with a brief overview of the early understandings of the term 'identity politics' in the United States. Moving beyond interest based movements I explore Maria Lugones' particular understanding of the self as multiplicitous. I then offer examples of the Muslim identity within the context of a social movement and individualist claims, in order to draw out the political aspects of the Muslim identity. In the final section I argue that the theological criteria that defines 'who counts as a Muslim' is a crucial aspect of how many Muslims may understand their identity as Muslims. However, I claim that in order to avoid the traps of marginalization of Muslim minorities, one must understand oneself as a multiplicitous political agent and that furthermore, such an understanding is not at odds with Islam or one's own understanding of their identity as Muslim.
\end{abstract}

\section{Introduction}

The term identity politics loosely represents political resistance grounded in the shared experiences of oppression of people. The 1960's saw the emergence of identity based liberation movements throughout the United States such as the Women's Liberation movement, the Black Power movement, gay and lesbian rights movement, and Chicano movement, amongst others. The common thread amongst them is the idea that members of such social groups are oppressed precisely because of their membership in those social groups. Consequently, the most basic element of identity politics followed from two claims: identity is tied to interests and politics is interest-based. According to the logic of identity politics, to effectively counter the roots of oppression, political resistance must be tied to their identities in virtue of which one is subject to oppression. Thus, engaging in politics meant advocating for one's interests, where one's interests are determined by one's social group membership.

Later versions of identity politics, however acknowledged the shortcomings in such an understanding to resistance. Elizabeth Spelman in Inessential Woman describes the basic problem that results from employing, what she terms as, an "additive analysis." No social group specifically 
addresses the concerns of individuals who may be part of many marginalized groups and only regards their specific concerns as additional concerns, when in fact they are different concerns. ${ }^{1}$

\section{Identity Based Liberation Movements in the United States}

María Lugones employs the terms "transparent" and "thick" to explain this idea, terms I use throughout the paper. ${ }^{2}$ Individuals are said to have transparent interests if their interests are perceived as the interests of the most dominant construction of the group identity. "Individuals are thick if they are aware of their otherness in the group ... being relegated to the margins in the politics of intragroup contestation" 3 . Thick members are both visible - as aggregate members with "culture", and invisible - as themselves, whole. They are viewed as composites of the transparent members of various groups, and more importantly, their "interests, needs, and ways of seeing and valuing things, persons, and relations are understood not as tied simply to group membership, but as

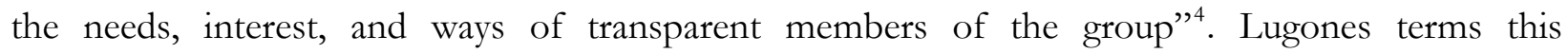
phenomenon of being viewed as a composite of transparent interest as fragmentation. Earlier theoretical versions of identity politics were not perceptive to the disenfranchisement resulting from fragmentation, one being understood as mere sum of interests of the most dominant construction of an identity, rather than as multiplicitous and inseparable. The self is viewed as parts and those parts are viewed as whole.

Lugones develops further the idea of self as multiplicitous and inseparable. ${ }^{5}$ She writes about the art of making mayonnaise, where attempting to separate the white from the yolk, the yolk often stains the white. Any attempt then to cleanly and purely separate one from the other goes in vain. And if the two do separate cleanly, and the oil is added too quickly into the mixture of water and yolk, it curdles. She compares the first analogy of separating the yolk from the white as illustrative of the logic of purity. The logic of purity produces misleadingly united and fragmented subjects, products that are tools to control creativity and multiplicity of subjects. Members with transparent interests portray a fictional unified essential human nature that is governed by reason, where all their attributes such as their whiteness or affluent social class become incidental to their existence. Whereas thick members are defined by their pieces, by their incidental attributes, their cultural, economic or racial markers, and those markers are taken for the whole.

However, like the yoke that has 'stained the white' thick member interests can never be cleanly separated from transparent interests, nor can they be taken for whole. However, for mainstream society, unless the thick member's interests can be understood in terms of additive analysis of the concerns of transparent interests, they are seen as "anomalous, deviant, ambiguous, impure."

The second analogy of adding the oil too quickly illustrates the 'logic of curdling' which is an exercise in impurity, in multiplicity, in being an unstable emulsion, a "haphazard technique of survival as an active subject, or it can become an art of resistance, metamorphosis, transformation."7 "Curdle-separation is not something that happens to us but something we do...in resistance to the 
logic of control, to the logic of purity." 8 Thick members resist definition in terms of transparent interests. Like the oil added too quickly, we curdle and coalesce toward our own, yet are inseparable from our fragments.

The logic of purity keeps us away from seeing the continuities amongst thick members because we become restricted in our communication through the disconnected language of transparent interests alone. For Lugones, we become agents of oppression ourselves for other curdled beings by following the logic of purity, by organizing ourselves into the neat orderly world of the lover of purity.

The way to not be agents of oppression ourselves, we must resist seeing ourselves and others in neat separable categories. People who are our own are not merely restricted to those who share similar social locations. Rather all liminals, all curdled beings, those of us in the margins are "our own." This is the only way to avoid the vicious cycle of fragmentation. By being restricted to the dichotomies constructed by the logic of purity, we become unaware of the people in different social locations who are also marginal.

Lugones clearly departs from seeing politics as simply interest-based, because it is not our identity as African American, Woman, Chicano, etc. that ties our resistance together. Rather, it is the fact that we are all liminals in a society that blocks us from seeing the connectivity amongst us. It is only through embracing each other can we truly overcome the logic of purity that prevents us from making sense of our world.

The critique of additive analysis and fragmentation exposes the fatal flaws within the discourse on identity politics, as relying on any framework of interest-based politics leaves thick members who fall under the umbrella of that identity disenfranchised. For the purpose of carving a political identity for Muslims, I endorse Lugones' understanding of the self as multiplicitous. I discuss this in the last section and resolve the seeming contradiction between the essentializing definition of a Muslim and the multiplicitous nature of the political agent.

In the following sections, I explore examples of the Muslim identity within political movements and individualist claims in order to illuminate political dimensions of our identity.

\section{Examples of Muslim Identity}

Here, I very briefly describe the role of Muslim identity in Pakistan's independence movement and within individualist self-proclamations of the identity. I shall use these examples in the following section, to delineate the ways that the Muslim identity may function in people's lives politically and examine its working within the context of community, body and practices.

Muslim Identity-based Social Movement 
The Muslim identity was at the core for the fight for independence of Pakistan and yet Islam as a religion was not expected to serve as a model of government for the country it would form. Many of the speeches within the independence movement focused on the connectedness amongst Muslims, not only based on the oppression we faced in virtue of our identity, but also a positive notion of identity - 'a moral consciousness' shaped by Islam'. Thus, religion molded our sense of political ethics. However, the significance of this movement is not the mobilization based on religion, but the a-religious component of the religious identity. The independence movement referenced a religious identity, but the movement itself was political in nature and centered on the right of Muslims to be free from British colonization, and Hindu domination. The movement ultimately resulted in Pakistan in 1947, which became the Islamic Republic of Pakistan in 1956, with institution of "Islamic laws" during the military dictatorship of - U.S. backed - Zia-ul-Haq (1977-1988). In terms of the purpose that the founder of Pakistan, Mohammad Ali Jinnah envisioned, many would argue that Pakistan failed miserably, as religious minorities are often treated as second class citizens. However, the central idea behind the movement itself - rally utilizing a religious identity for a political cause forces us to navigate elements of the identity so Muslims today can have both, the hope of not betraying their faith in Islam and have a meaningful political existence.

\section{What Kind of Muslim are you?}

\section{Three Individual Cases}

Kulsum bibi, our aunt, genuinely seems to be at peace with God. A widower at a young age, she prays five times a day, fasts the entire months of Shaban and Ramadan, does not go to gender desegregated gatherings, and exudes the confidence of a person who knows why she does what she does, without being on a moral high. At all times, the most important signifier of her identity, she claims, is being a Muslim.

Irshad Manji, an Indian/Egyptian descent Canadian and self identified Muslim, wrote The Trouble with Islam ${ }^{10}$ and landed multiple spots on all major British, Canadian and American television networks. In her book, she expresses discontent with the state of Islam and of Muslims and declares that she is barely hanging on by her fingernails. She gives a selective history lesson of the wrongs committed by Muslims and Muslim governments around the world, ending with a chapter graciously thanking the hospitality of the West in embracing Muslims and Islamic culture. The book is a personal memoir and a political analysis as an "insider."

Akeel Bilgrami, a self-professed atheist, looking for a place to stay in India in a Hindu neighborhood hostile to Muslims, is asked by a landlord of a certain establishment about his religion. Bilgrami finds himself saying, "I am a Muslim. ... It still seemed the only self-respecting thing to say 
in that context. It was clear to me that I was, without strain or artificiality, a Muslim for about five minutes." 11

Kulsum Bibi, Irshad Manji and Akeel Bilgrami represent diverse, not necessarily mutually exclusive, ways in which different people identify as being Muslim. But who actually counts? Can Bilgrami, a self-proclaimed atheist, count or Manji, a political dissident who supported the war in Iraq and the wall on Israeli border? Is Kulsum Bibi the only legitimate kind of Muslim, the one that has religious faith in the tenets of Islam?

\section{Complexities of Muslim Identity within Politics}

The question of authenticity has plagued earlier versions of identity politics, where Eric Motley is considered 'not black enough' because of his political alliances, ${ }^{12}$ or where someone with ambivalent phenotypes may not be accepted as experiencing the 'authentic' black experience. The question of who counts takes on an added component when applied to Muslims. The identity is religious in nature and thus, is assumed to have a defined theological criterion.

The idea of a qualifying criterion has strong implications within the civil and political sphere. For example, since the institution of 'Islam' into laws during General Zia-ul-Haq's rule, Pakistan has suffered from sectarian divide of unprecedented levels. As only one interpretation of Sunni-Islam took hold of the state, partly in response to the Shia-Iranian Revolution, every other interpretation was invalidated as polluting 'pure' Islam. There are no official studies of the number of Shias killed since the time of Zia-ul-Haq, but the news is always generously sprinkled with assassinations of Shia community leaders, doctors, other professionals, massacres of entire villages, explosions of mosques, and consequent retaliating violence. The violence has targeted both Shias and Sunnis but nowhere as proportional $^{13}$. The perception in the minds of few is that Shias and other Muslim minorities like Sufis and Ahmedi Qadayanis do not practice a legitimate version of Islam, hence are not Muslims. The question of true "Muslim-ness" is positioned at the center of all this violence and political theory has to accommodate a way that allows Muslims to hold on to the theological aspects of the identity, while avoiding the political marginalization that ensues. I shall deal with the theological criteria towards the end of this paper.

In this section, I draw on the theoretical discourse on identity politics within the U.S. academic context and the examples from the previous section to provide us with a starting framework to explore the a-religious aspects of Muslim identity. I explore three significant ways in which one may understand one's Muslim identity beyond the theological criteria: belonging to a Muslim community (ummah), occupying a Muslim body, and habituating oneself through practices associated with the religion. The idea of culture is, perhaps more significant within the Muslim context because practices are generally tied to the theological framework, and thus are linked inextricably with one identifying or being identified as a Muslim. Exploring identity through the idea of community, our bodies and our practices does not imply that that there are not other contexts in 
which one may identify oneself as Muslim, rather these three ways offer us insight beyond the theological criteria for political navigation.

\section{a) Muslim Community}

The literal translation of ummah from Arabic is community or nation. It is generally used to refer to the notion of a united Muslim community. The concept of ummah is most often politically evoked at Organisation (sic) of the Islamic Conference (OIC) meetings. Leaders of OIC, Arab and non-Arab, stress the ummab's fate being tied together to mobilize for purely political purposes. Historically though, the word encompasses a larger idea. The Qur'an uses ummah to refer to the entire world, humankind as one community, as well as to refer to Muslim believers in particular. Similarly, the written constitution of Madina drafted in $622 \mathrm{CE}$ refers to Jews and pagans as part of the ummah.

I explore the amebic boundaries of ummah in three specific ways: through one's religious grounding, by our interaction with the Other and through an imposed image of us by the Other. I begin with religious grounding of ummah. Within the context of the political Muslim world, the word signifies a strong idea of pan-Muslim unity, of all of us holding tight to the rope of God (Qur'an 3:103). The idea of ummah does not transcend race, nationalities and ethnicities, rather works with them based on the shared axis of faith in God (Qur'an 49:13).

The idea of pan-African identity or universal women's category was common in the early versions of literature on identity politics. A pan-Muslim unity bears an added component when contrasted with those early notions. The idea of unity is not necessarily grounded in an assumption of shared experience of oppression, or a system of oppressive axis. The rich Kuwaiti oil sheikh and the poor Somali woman do not share race, nationality, social class, gender, and more importantly, possibly any imaginable experience of oppression based on their identity as a Muslim, yet both ought to count under the umbrella of ummah. Faith serves as the shared axis.

However, the internal bindings of the idea of an ummab united by religious principles have had both negative and positive implications for political mobilization. Political movements based on the idea of one Muslim community often assume shared interpretation of faith and consequently political

strife on who shall count as a part of this ummah. In this sense, the idea of ummah can be very limited in its scope and political mobilization based on this idea can leave many politically disenfranchised.

For example, many of the leading figures in Pakistan's independence movement were minorities under the umbrella of Indian Muslims: Mohammad Ali Jinnah was Itna Asheri Shia (Khoja), Fatimah Jinnah, his sister, was Shia and a woman; major support for the movement was from Bengal Provincial Muslim League (BPML) with leaders such as A.K. Fazlul Huq, Shaheed Suhrawardy and Abul Hashim being key players in ridding the Subcontinent of the colonial rule. More than half a century later, Pakistan is torn by Shia-Sunni sectarian strife and women's rights took a step back during second martial law. Furthermore, Bangladeshis, being denied their basic 
rights such as proportional representation in government, in resource allocation and language enforcement, eventually fought for independence in 1971 from West Pakistan. So although, the mobilization for independence of Pakistan was based on the Muslim identity, the movement illustrates that political marginalization is bound to occur when the theological criteria for ummah is evoked.

The formation of ambivalent definition of ummah is also affected by our engagement with the Other. We see the concept of ummah invoked to rally people to fight fights that are not perhaps their own. The manifestation of the Cold War between the United States of America and Russia played out in Afghanistan, resulting in a strong formation of an Afghani Muslim identity based in resistance. The Afghanistan government requested Russian assistance to fight rebellions within its borders, while the United States government gave its entire backing to the rebels. The ideology that was deployed on a large scale to mobilize the Afghanis to fight the Russians was one that emphasized connection with other Afghanis by faith. The Russians were godless communist infidels, while the Afghanis were believers. The famous picture of President Regan with Taliban leaders, calling himself as one of the Mujahideen (one who fights jihad) or "freedom fighters" as he termed them, forms clear in the minds of those who now live under the consequences of a Taliban outlook. The formation of what it means to be a Muslim community, formed during that war still entrenches not only Afghanistan, but also northern regions of Pakistan and has had great impact on the Shia-Sunni violence in Peshawar, Quetta, Lahore, and Karachi, not to mention on the 'war on terror'. So the jagged borders of what it means to be a Muslim nation is formed not just with manifestations of conflict within, but also through our encounters with the Other.

The third kind of definition of the Muslim community comes from an imposed image of us as a monolith entity by the Other. Media outlets are strewn with references of Muslim Americans as homogenous, having a uniformity of political opinions and loyalties. On the rare occasions that representatives from Muslim interest groups are on television, they are asked to present the view of the Muslim American, or the Muslim vote.

Madmood Mamdani explains this phenomenon as "Culture Talk." It is the assumption "that every culture has a tangible essence that defines it, and it explains politics as a consequence of that essence... 'Islamic terrorism' is thus offered as both description and explanation of the events of 9/11." "14 The idea behind such portrayal is that the essence of Islam is in clash with the core values of the West. ${ }^{15}$ According to the "clash of civilizations" theory, Islam divides its view of the world into two: the House of Peace (Islam) and the House of War. ${ }^{16}$ Hence, it is inherent in our faith, and consequently within us, to always clash with non-Muslims. "(E)ven when Muslims appear peaceable, the inherent logic of their faith belies such appearance; to trust in it would be foolhardy." ${ }^{17}$ Such characterization defines the essence of being a part of ummah in opposition to democratic, pluralistic, peace-loving, freedom fighting, democracy bringing, Kumbaya singing, hand-holding (especially of Muslim women, being oppressed by their patriarchal backward religiously fanatic culture), treehugging, but of course hard-headed secular West. Such logic has resulted in essentializing our inherent character. 
There are definite political consequences of having a contested theological criterion of Muslim ummah and of having an imposed-upon homogenous understanding of what it means to be a part of it by the other. Furthermore, being part of the collective, whatever that means to each person, cannot be considered a distinct, separable or private aspect of the self.

\section{b) Marked Muslim Body}

The notion of marked bodies has strong parallels within the discourse on identity politics in United States. However, it may not be the lens through which Muslims view their own identity as Muslims. From African Americans, Africans, South Asians, to Arabs, Persians, South East Asians, Whites, and East Europeans, Muslims not only differ in their nationalities, culture, dress norms, and race, but also in their prejudices, loyalties, and political views. So to talk about a collective Muslim body is odd, because their bodies are not inherently marked. However, they are subject to people's perception of what a Muslim ought to look like. It is this perception of Muslim bodies that has dominated civil society, and subsequently their political existence.

In the wake of the 9/11 attacks in America, many Americans sought a target to displace their anger. They found Muslim bodies. But given Muslim diversity it was a selective group of individuals who became targets of violence, threats and frequent shouts of "go back to where you came from." Members of these selective groups were distinguished by their black beards, brown faces, a turban or a bijab or their South Asian looks. However those who were spared were the clean-shaven, "modernly" dressed, fair-skinned individuals who were practically indistinguishable by appearance from the average American Joe or Jane. The irony, however, is that the individuals responsible for the attacks fitted the later description. Nineteen out of the twenty-one hijackers were Saudis who a few days prior to the attacks were seen going to clubs, dressed casually in pants-shirt, clean-shaven and could best be described by appearance as "Mediterranean". Since then United States continued to maintain a great relationship with Saudi Arabia and since most Saudis look Caucasian, they had the possibility of avoiding the isolation doled out in this country if they managed to somehow blend in, i.e. become White. Many shaved off their beards, Mohammads became Mos, going out of their way to become acceptable, to become "good" Muslims. On the other hand, many donned beards where none were before or wore bijab to own up to their heritage, their religion as a sign of resistance and subversive defiance. Either way, how we perceived our bodies became molded by our perception through the eyes of the other. W.E.B. DuBois explicates this experience of self as double consciousness:

It is a peculiar sensation, this double-consciousness, this sense of always looking at one's self through the eyes of others, of measuring one's soul by the tape of a world that looks on in amused contempt and pity. ${ }^{18}$

American Muslims feel their twoness, socially constructed irreconcilable identities within the social and political context of today's world: as we define our identity as Muslims and as how others see us 
as Muslims. Thomas Slaughter expands on the knowledge that black bodies possess in virtue of the negative perception.

... [t] his social environment and my routine internalization of it are not only hostile to my individualizing ego; they are so constituted as to be explicitly antithetical to the very being I am to the world through my body. Between me and the surrounding world there exists a split of which by lopsided social contract, my body is the symbol. Blackness embodies the ostracized. Under the duress of racial domination, I undergo the now familiar two-pronged process of externally imposed inferiorization and subsequent internalization of that inferiority. ${ }^{19}$

Similarly, not only possessing a Muslim body became the symbol for the terrorism that shook this country, it also shook our own perception of ourselves. Since 9/11 White Christian America has become more informed of the distinction between the good Muslim and the bad. Yet, the one that is bad is precisely the one that is distinctively Muslim and visibly practicing. And as we internalize the notions of what it means to be a bad Muslim, we limit our political possibilities in the world around us, distancing our bodies and our attitudes from those perceptions. So even if one wears a bijab in resistance, "I create a person. But I own nothing. I borrow things. And in the end I give language back to the environing society." 20

\section{c) Muslim Practices}

The most significant way that Muslim Americans identify themselves as Muslims is through our practices. Our practices mark our consciousness by way of exclusion, accommodation, representation and experiencing a connection of being same or at least similar to each other. More than that, they form our characters through lifelong habituation of a way of life.

The prevalent perceptions of Islamic practices can be considered distinct from Islam, the religion. One of the most common defenses of Islam against charges of misogyny and patriarchy is that Islam is misunderstood. It is associated with practices it is not connected to, sometimes by the Other and sometimes by us. The identity is essentialized through cultural practices. Practices that are local to a region, such as female circumcision in parts of Africa, are viewed as part of the inherent Islamic practices that make Muslims, in particular Muslim men, Muslims. Hence, when we defend our religion against such unfound charges, we are quick to point out the line between religion and a perverted culture that has been shaped through patriarchy, colonialism, and exploitation. Even when mainstream media attempts to show respect to Islam, it is shown through praising a static culture, arising from invariable codes of ethics. 
When we speak of religion or its people by the way of such discourse, we assume that culture is made only at the beginning of time, and since is set in stone. Mahmood Mamdani terms such discourse as "culture talk", where our practices, and consequently our political actions are attributed to arise from static founding texts. ${ }^{21}$

According to some, our culture seems to have no history, no politics, and no debates, so that all Muslims are just plain bad. According to others, there is a history, a politics, even debates, and there are good Muslims and bad Muslims. In both versions, history seems to have petrified into a lifeless custom of an antique people who inhabit antique lands. Or could it be that culture here stands for habit, for some kind of instinctive activity with rules that are inscribed in early founding texts, usually religious, and mummified in early artifacts? ${ }^{22}$

However Islam is represented, it is used to defend, define, and explain away our actions, our habits, our societies and our political directions. The logical question that arises then is how else are we to speak of the significance of culture for political Islam?

To label any experience as the Muslim experience would be to homogenize the diversity of Muslims. No one Muslim's experience would be exactly like another, simply because they both have faith in God. However, people may "feel" their Muslim-ness by way of exclusion. They may not be sharing the same experiences because they both necessarily have faith, but more specifically the experience of exclusion elicits their identification with the Muslim identity. Let us take the example of Bilgrami. The umbrella of Muslim identity is encompassing enough to allow Akeel Bilgrami, the selfprofessed atheist, to claim experiencing it without any strain of artificiality. He was aware he was in a Hindu neighborhood at time when tensions between Hindu and Muslims ran high. His sense of exclusion prompted his identification. Similarly, when the Republican Nominee for 2008 U.S. Presidential Election, John McCain, made statements to the effect that he would prefer a Christian president, that exclusionary posture made even the least theologically committed American-Muslims become aware of their Muslim-ness. ${ }^{23}$

One may also experience their Muslim-ness by way of accommodation of our practices: on university campuses across the United States, Muslim Student Associations (MSA) have a room assigned for daily prayers for the convenience of Muslim students. As we walk in and out from that room we experience our Muslim-ness by way of being accommodated.

Our practices also define boundaries of dissention within. The absence of representation of minority practices such as the significance of Muharram to the sustenance of Islam in "Islamic Awareness Week" throughout U.S. campuses or complete erasure of certain religious practices as unIslamic, makes minorities more aware of their identity. Thus, the Sunni led governments of Bahrain, Pakistan, Yemen, Lebanon, and Saudi Arabia, do not represent "authentic" Islamic practices to their Shia citizens. The state instituted Islam makes these citizens become aware of their particular brand of 'Muslim-ness' through marginalization or often complete ban of their practices. 
The relevance of Islamic practices within politics goes beyond self-identification by way of exclusion, accommodation and representation. It authors the scripts we follow. Alison Bailey writes about the notion of scripts that we follow as "expected performances, attitudes and behaviors" taught to us from early childhood. We animate our performances through our "gestures, language, attitudes, concept of personal space, gut reactions to certain phenomena, and body awareness." Our practices as Muslims ingrain in us the scripts we follow. This goes beyond the idea of mere culture talk. It is about attitudes shaped by our daily routines.

For example, wearing a swimsuit that does not cover appropriate parts of the body is antithical to Muslim values of modesty. This rule does not apply to children under puberty. And although I am aware of this, because I have been raised in a certain way, I was reluctant to have my infant daughter wear a swimsuit (that someone gifted to us) to the pool, even though she was barely one. I rather have her simply wear her swimming diapers. My behavior has little to do with Islamic law itself, but the habituation of those laws have affected me in ways beyond their scope.

A more politically apt example is the remembrance of the battle of Karbala for the Ithna Ashari Shias. The battle was between the family of Imam Hussain, the grandson of Prophet Mohammad, and the Muslim caliphate of the time. From the first of Moharram, the Shias hold majlises, gatherings. The momentum builds up to Ashura (the tenth day of the month of Moharram), the day that the men of the Prophet's progeny were brutally murdered. The women were taken as prisoners of war, paraded through the Islamic empire as examples of what happens to dissenters. Shias mourn the merciless deaths and the captivity, and celebrate the resistance.

The battle was unlike a traditional Islamic battle in the sense that Imam Hussain was not in active preparation of an armed confrontation. He never declared war against the Caliphate, yet he refused to recognize Yazid's caliphate as legitimate. Secondly, he had his entire family accompany him to Kufa, including the women. Generally only men traveled for battles. This showed his intent to migrate. Thirdly, and most importantly, he was aware that his refusal to pledge allegiance to the Caliphate would lead to a deadly war against an outrageously outnumbered army of Yazid.

The political temperament of Shias is shaped by their yearly remembrance of this war. They remember it by sitting on the floor together, solemn, crying for those who died while someone narrates the events then they stand up and beat their chests with their hands as they remember and celebrate the courage of the martyrs. The entire month has a somber, yet charged atmosphere. The way they commemorate it preserves its intensity, the raw emotions ${ }^{24}$.

Over centuries, the narrative of Karbala has resonated and endured with Shias such that it has molded their political posture. The narrative has become a rich and readily available reservoir of sentiments of opposition to tyranny and injustice, and a distrust of corrupting political power. The constant ingraining of the lessons shapes one's mind to know that one has an obligation not to accept oppression for the sake of mere order, but not launch a confrontational resistance merely for the sake of power. It is resistance based in consciousness, in words, and when confronted, it is resistance in terms of actions. Such practices have shaped our way of moving politically through the world. 


\section{Theological Essentialism}

Kulsum Bibi identifies herself as a Muslim. She claims to believe in Islam as her way of life. She belongs to the Salafi school of thought and considers many practices of her Dawoodi Bohra family, her Itna Ashri Shia and Hanafi acquaintances as un-Islamic. She believes that it is her daily exercise of Islamic practices that show her devotion to God and affirms her commonality with other Muslims. Her chador, that covers her head and upper torso completely, is her expression of her faith and marks her body as a religious body within a pre-dominantly Muslim society of Karachi.

Irshad Manji identifies herself as a Muslim. She grew up disenchanted by organized religion and explored her spirituality outside of it. She faults Islam for closing the doors on ijtihad (coincidently, Shia Muslims do believe in it) and believes in Islam permitting homosexuality (which many other gays and lesbians have argued for using the Qur'an ${ }^{25}$. However, it is not her unorthodox interpretation that sets her apart for the purpose of understanding political Muslim identity, but more importantly, it is her political views. She defends the invasion of Iraq, sympathizes with the Israeli wall and characterizes Israeli army's treatment of Palestinians as compassionate. She thinks that the "West" has been hospitable, that 'Islam' is not, and dubs Muslims as fake victims who wallow in their self-pity.

Her book belittles the struggles of Muslims around the world into a monolithic representation of "good" moderate-minded Muslims like her, and the "bad" Muslims who stand against democracy and liberal values. The American media has embraced her as the representative of "good" Muslims, with an ongoing list of awards for her courage to speak up against the "bad" Muslims. Her narration of selective events erases the diversity of political views amongst Muslims and the intricate history of coexistence of Muslim and non-Muslim communities. It has reduced it to a version soothing to the souls of Americans who cannot reconcile any version of the theological Muslim - other than the 'Good Muslim' - with "American" values. On her official website, there is a flashing message: "My name is Irshad. I am a faithful Muslim". ${ }^{26}$ (emphasis added).

Atheist Akeel Bilgrami identified himself as a Muslim in a particular moment. He claimed his Muslim-ness for a few minutes in a moment when he felt that it was the only self-respecting thing to do. He points in his footnote that "Someone with no theological commitments might feel a sense of identity with Islam in contexts as diverse as: when he feels shame at the actions of Muslims - as say, the Muslim response to the publication of Rushdie's The Satanic Verses; when he feels concern about the future of Muslims in some hostile area- as say, in parts of India or England; or quite simply by an intellectual inheritance of public-mindedness from the fact that his family has been involved in Muslim politics for a very long time. There is no interesting common thread running through these different contexts." 27 For Bilgrami, it appears that a sense of identification comes from one experiencing it through a variety of ways, whether its exclusion within hostile environments, inclusion within a political discourse and possibly having practices/culture habituated through childhood. His social location within the power dynamics of India materialized in his mind with the 
landlord's question and it shifted his way of seeing the world, allowing him to move through the world as a Muslim.

What defines us as Muslims individually and as a people? How one answers these questions may translate politically into marginalization within the ummah and essentialization of the Muslim outside. One bare minimum normative definition of 'Muslim' is that a Muslim is a person who believes in One Omnipotent God and believes in the finality of prophets with Prophet Mohammad (pbuh). Different schools of thought often have additional criteria (e.g. belief in the Day of Judgment etc.), all of which leave pressing questions for Muslims to resolve within the political arena. Who gets to be the gatekeeper of who counts as a true Muslim and who falls short of measuring up to the criteria?

In this section, I take up these concerns as related to their political ramifications. I divide this issue into two: (a) the task qualifying Muslims as taken up by members of dominant constructions of that identity and (b) the conflation of the essentialist nature of Islam with the essentialist nature of its practitioners. The first task deals with the issue within the theological realm and the second allows for hybridity of the Muslim agent, without losing the theological aspect of the identity which maybe indispensible to how some may understand themselves as Muslims.

\section{Marginalization Within}

For many, the way that they see themselves as Muslims is that Islam has an essence and meeting certain criteria makes one Muslim. Often times, one may see amongst some Muslims a tendency of speaking as if they own Islam or possess the guardianship of morality and hence, a right to judge others. Such an attitude by dominant members of society toward others erases the voices of those who are marginal. The politically marginalized are branded as not worthy of staking moral ownership within the religion, and consequently their concerns are not the concerns of the ummah. In Lugones' terms, 'thick' members, such as Shias in Sunni majority communities, or women in male-dominated associations, are rendered non-sensical as they are reduced to voicing their concerns within the framework of additive analysis of transparent interests. Lugones quotes a telling incident about who are 'our own' people:

A tortillera ${ }^{28}$ is putting up posters in Tucson for an event sponsored by several organizations. As she asks a shop owner whether she can put a poster in his shop, he says: 'Yes, if you cut out that sponsor,' pointing at 'Lesbianas Latinas de Tucsons.' La tortillera says, 'What, are we not part of la raza?' 'Not of my raza' says the man. ${ }^{29}$

The question for Muslims is further complicated because we think we know precisely why they are not part of our raza, our ummah. We measure them up against the criteria in our head, and if they fall short, we are quick to disqualify them from our struggles because they do not speak as true Muslims. But it is precisely this marginality, this viewing of the world in neat categories of Muslim and not-quite- 
the-right-Muslim that Lugones warns us against. For Lugones, the only way we can escape this vicious cycle of fragmentation is to reject the logic of purity altogether, to claim all as our own.

For Lugones, 'thick' members must reject the dichotomies they are presented. Furthermore, 'thick' members must not simply claim as their own other liminals who reject the same dichotomies they do, but all liminals who reject the logic of purity, who refuse to communicate in the language of transparent interest. Only then can we be free from being bound in a world defined neatly by transparent interests. Only in this way can we move from one political space to another without experiencing betrayal, can we transgress the idea of social enclosure and re-appropriate political space.

For Muslims, this presents a problem because a theological understanding is precisely how many Muslims understand their identity as Muslims. That is, if asked: 'How are you a Muslim?,' many would respond: 'because I believe in Islam' or 'because I believe in Allah and Prophet Mohammad (pbuh).' The point here is not that all Muslims understand themselves in this way (as in the case of Bilgrami), but that the theological aspect of the identity is indispensible to many. To sidestep the theological understanding of the identity would be to discredit how agents see themselves as.

However, political marginalization does not occur because of a theological understanding but its application to measure others' 'Muslim-ness.' The normative Islamic understanding of who is a Muslim does rely on an essence, however, the morally required epistemology forbids one to judge how and which sins may be forgiven and which ones disqualify a Muslim completely. In other words, the question of who has/practices the essence of Islam is a question that the morality dictated by Islam forbids one to pursue. Any person who claims that he or she is Muslim, is a Muslim. This does not imply that Muslims cannot pinpoint actions as un-Islamic. Indeed, standing up against injustice is required. However, judging individual actions as unjust is different from placing it in context of one's life and judging a person's "Muslim-ness."

In Surah An Nisâ' (The Women), ayah 94, the Qur'an states that we ought not discredit anyone who states that they are a Muslim by doubting their intentions of stating as such, for it is for God to decide. In Surah Al Hujurat (The Chambers), ayah 11 and 12, the Qur'an states that we ought not to ridicule other people or make negative assumptions about them, because we may not know it and they maybe better than us. Only God knows best.

Thus, the normative prescription in Islam is that it is not for us to judge others' faith, question their self-identification as Muslim, or their intentions behind such self-identification. No Muslim ought to contest a person's faith, and consequently marginalize their voice as not part of the struggle on that basis. Some may study the religion far more than others or may be dear to God in virtue of their character, and hence may be deemed religious authorities. Yet, no one person can be an authority on disqualifying another Muslim as a Muslim. Such an understanding of our identity within the political realm allows Manji to speak as an insider - as she claims, and as many contest. 
Her political views deserve debate on their merit as opposed to discrediting her voice on the mere basis of contesting her claim as a Muslim.

\section{The Conflation}

As stated earlier, Islam, the religion, has an essentialist nature. There are definite theological mandates stated in the Qur'an that define the religion. This essentialist nature of the religion cannot be cleanly separated from the practitioner of Islam who follows their interpretation of the religion. That is to say, to discount the essentialist nature of Islam is at odds with most practitioners' understanding of how they practice their religion.

However, this understanding is not at odds with the multiplicitous self, one that allows each person to claim their interpretation of essentialist Islam in their lives. I argue that there is a conflation of the character of Islam with the characteristics of its practitioners. The Muslim political agent does not have an essentialist identity merely because their understanding of Islam is essentialist. The practitioner of the religion experiences elements such as faith, a sense of belonging to the ummah, our bodies, our practices, etc., that have theological mandates evolved through our specifically located lives. There is no cleanly separable part of the self that is the 'pure Muslim' and then added to this fictional 'Muslim'; there are other aspects of our identity, like our gender, socioeconomic status, duties to our country, etc. Rather, the Muslim political agent is a multiplicitous self, where an evolution of elements makes us claim ourselves as Muslim.

A conflation of Islam with its practitioners essentializes our political identity into one singular identity, such that the commonalities amongst us are missed out because we too are separating those that qualify from those who do not. As Muslims, we habituate the theological mandates throughout our lives within the specificity of our social location. It is within our specific environment, whether that'd be the environment of a Taliban fighter, once a child of an Afghani Mujahideen from Cold War era or Akeel Bilgrami's secular but with hints of Islamic elements childhood, that gives us that sense of identification with Islam. The Taliban fighter, Professor Bilgrami, Kulsum Bibi, Irshad Manji, all are complex, multiplicitous selves, where no part can be separated and labeled as 'Muslim.' For some, like Kulsum Bibi, this identification is an overriding moral commitment. For others, it guides their political commitments or acts as incidental social location that makes them privy to certain vantage point.

\section{Conclusion}

This paper explored the Muslim identity beyond the theological aspects associated with it. While theological understanding is indispensible, it is essential to recognize that there are many threads within our lives that interweave to prompt a person's identification with the term 'Muslim.' I have to emphasize that for many, such as myself, what makes us a Muslim is our faith in Islam, in God, in 
Prophet Mohammad (pbuh), in the Day of Judgment, and not our political leanings. Yet, within the present geo-political atmosphere in the United States, the term 'Muslim' is often regarded as a political block, lumped together, rallied together and often in resistance together. Within such an environment, it is important to carve out a political identity that allows us to participate as Muslims, without marginalizing minorities within. With the aim of political participation at the forefront, it is imperative to embrace the understanding of self as multiplicitous. Our imaginary bonds within the amebic boundaries of ummah, our consciousness of the markings on our bodies and our life long habituation of a way of life, all evolve within the specificity of our lives, and locate our participation as Muslims.

\section{NOTES}

1 Elizabeth V. Spelman, Inessential Woman: Problems of Exclusion in Feminist Thought, Boston: Beacon Press, 1988, p. 23

${ }^{2}$ María Lugones, Peregrinajes/pilgrimages: Theorizing coalition against multiple oppressions, Lanham, MD: Rowman \& Littlefield Press, 2003

${ }^{3}$ Ibid., p. 140

${ }^{4}$ Ibid.,

${ }^{5}$ Ibid.,

${ }^{6}$ Ibid., p. 125

${ }^{7}$ Ibid.

${ }^{8}$ Ibid., p. 144

${ }^{9}$ Allama Iqbal,, Speeches, Writings, and Statements of Iqbal, Compiled and Edited by Latif Ahmed Sherwani, Iqbal Academy, 1977;

http://www.columbia.edu/itc/mealac/pritchett/00islamlinks/txt_iqbal_1930.html (last accessed Nov. 4th, 2008)

${ }^{10}$ Irshad Manji, The Trouble with Islam: A Muslim's Call for Reform in her Faith, New York: St. Martin Press, 2003. In a later edition the book was renamed: The Trouble with Islam Today.

11 Akeel Bilgrami, "What is a Muslim? Fundamental commitment and cultural identity", Critical Inquiry, Vol. 18, Issue 4, 1992, pp. 822.

${ }^{12}$ William Haygood in Being a Black Man: At the Corner of Progress and Peril, Kevin Merida ed., New York: PublicAffairs, 2007

${ }^{13}$ In a non-comprehensive listing of Shias and Sunnis killed from 1994-2002, Ardeshir Cowasjee lists 177 Shias vs.52 Sunnis killed in sectarian violence. Ardeshir Cowasjee, "In the name of Religion” Dawn, Karachi, Sunday, 10 March, 2002.

14 Mahmood Mamdani, Good Muslim, bad Muslim: America, the cold war, and the roots of terror, New York: Pantheon Press, 2004, p. 17.

${ }^{15}$ Samuel P. Huntington, Clash of Civilizations and the Remaking of World Order, New York: Simon \& Schuster, 1996.

${ }^{16}$ Bernard Lewis, 'The Roots of Muslim Rage’ in The Atlantic Monthly, September, 1990. 
${ }^{17}$ Emran Qureshi and Michael A. Sells, 'Introduction: Constructing the Muslim enemy' in The new crusades: constructing the Muslim enemy. Michael Anthony Sells and Emran Qureshi, eds., New York: Columbia University Press, 2003, p. 4.

${ }^{18}$ W. E. B. Du Bois, The Souls of Black Folk, New York, Avenel, N.J.: Gramercy Books, 1994.

${ }^{19}$ Thomas F. Slaughter Jr., 'Epidermalizing the World: A Basic Mode of Being Black', Man and World, Vol. 10, 1977, p. 304.

${ }^{20}$ Ibid., p. 307.

${ }^{21}$ M. Mamdani, Good Muslim, op. cit.

${ }^{22}$ Ibid., p. 18.

${ }^{23}$ In response to a question about the possibility of a Muslim running for President: "I just have to say in all candor that since this nation was founded primarily on Christian principles, that's a decision the American people would have to make, but personally, I prefer someone who I know who has a solid grounding in my faith," (U.S. Presidential candidate, John McCain Sept $29^{\text {th }}$, 2008) Or: McCain's denouncement of his supporter's characterization of Obama as being an Arab, hence not trustworthy as an American President: "No ma'am, no ma'am. He's (Obama) a decent family man, citizen that I just happen to have disagreements with on fundamental issues. That's what this campaign is all about. He's not (Arab), thank you.” (McCain $10^{\text {th }}$ Oct, 2008).

${ }^{24}$ This is how many Shias have experienced Moharrum. However, again, the experiences of Moharrum and derivative political posture for many, does not imply a homogenous experience for all Ithna Ashari Shias' experiences of the month.

${ }^{25}$ Kugle argues that LBGT communities approach the Qur'an with dual strategy of resistance and renewal, resisting hegemonic interpretation, offering a constructive alternate reading of the text. Scott Siraj al-Haqq Kugle, Homosexuality in Islam: Islamic Critical Reflection on Gay, Lesbian, and Transgender Muslims. Oxford, UK: Oneworld Publications, 2010, p. 40

Abou El-Fadl categorizes Islam's view on homosexuality as 'suspended judgment,' as there is at least room for debate whether homosexuality is permitted or not. Khaled Abou El-Fadl, Speaking in God's Name: Islamic Law, Authority and Women, Oxford, UK: Oneworld Publications, 2000, p. 28-30. Barbara Zollner argues regarding the story of the people in Prophet Lut's time 'that connotations of aggression are intrinsic to the Qur'anic passages in question...' Zollner then proposes a possible reconciliation within Hanafi school of thought, where anal penetration is considered licit within the realm of a licit relationship. Thus, theoretically, there could be room for rethinking marriage between same sex individuals. See, Barbara Zollner, 'Mithliyyun or Lutiyyun? Neo-orthodoxy and the debate on the unlawfulness of same-sex relations in Islam' in Islam and Homosexuality, Volume 1, Samar Habib ed., Sanata Barbara, CA: Greenwood Publishing Group, 2010

${ }^{26}$ Irshad Manji blog and official website: http://www.irshadmanji.com/ (last accessed Jan17th, 2011).

${ }^{27}$ A. Bilgrami. What is a Muslim? op. cit., p. 822.

28 'Tortillera' is a regional, Chicano slang word for lesbian.

${ }^{29}$ M. Lugones, Pilgrimages, op. cit., p. 169. 